\title{
Symbolic Meaning of Sere Bissu in Matompang Arajang Ceremony for Bugis Bone Community, South Sulawesi
}

\author{
Syahrianti Syam, Mahmud Tang, Safriadi \\ Pascasarjana Universitas Hasanuddin,Makassar,Indonesia \\ Fakultas IImu Sosial dan Ilmu Politik,Universitas Hasanuddin,Makassar,Indonesia \\ Fakultas IImu Sosial dan IImu Politik,Universitas Hasanuddin,Makassar,Indonesia \\ Email: syahriantisyam80@gmail.com,mahmud.tang@yahoo.com, safriadi65@yahoo.co.id
}

\begin{tabular}{|c|c|}
\hline ARTICLE INFO & ABSTRACT \\
\hline $\begin{array}{l}\text { Received } \\
23 \text { Juny } 2021 \\
\text { Revision } \\
1 \text { July } 2021 \\
\text { Approved } \\
10 \text { July } 2021 \\
\text { Keywords: } \\
\text { symbol meaning } \\
\text { ritual sere bissu } \\
\text { matompang arajang }\end{array}$ & $\begin{array}{l}\text { Matompang Arajang ceremony is a traditional ceremony that is still } \\
\text { passed down through generations and is still maintained until now by } \\
\text { bugis bone people. Matompang Arajang is a ritual of cleaning bone } \\
\text { royal heirlooms. Where the ceremony has a very important ritual that } \\
\text { is Sere Bissu. So far, previous studies have not reached the level of } \\
\text { finding the symbolic meaning of the Matompang Arajang ceremony. } \\
\text { This article aims to describe the process or stages in the Matompang } \\
\text { Arajang ceremony as well as explain the symbolic meaning of Sere } \\
\text { Bissu in the Matompang Arajangceremony. The method used is } \\
\text { descriptive-qualitative method with ethnographic approach. Data } \\
\text { collection techniques in the form of observations, interviews and } \\
\text { documentation. Data analysis is done with three stages, namely data } \\
\text { restatement, data description and data interpretation. These three } \\
\text { stages become the basis for drawing conclusions. Using } \\
\text { anthropological theory, the author explains the culture and meaning } \\
\text { used in the Sere Bissu ritual. The implementation of matompang } \\
\text { arajang ceremony includes malekke toja, mapaota, memmang to } \\
\text { rilangi, matompang and massossoro arajang. Sere Bissu ritual in } \\
\text { mattompang arajang ceremony has symbolic meaning as a form of } \\
\text { sacred communication to God as well as to the spirits of Bugis Bone } \\
\text { ancestors who they believe still exist around their lives. }\end{array}$ \\
\hline
\end{tabular}

\section{INTRODUCTION}

Bugis Bone people hold a variety of unique and cultural aesthetics that are highly respected and highly regarded. One of the cultures that still exist and color the social life of Bugis Bone people is mattompang arajang ceremony. Matompang arajang ceremony is a traditional ceremony that is still maintained by bugis bone people. The ceremony took place for generations as a reflection of the sustainability of bone royal heirlooms called arajang. Matompang arajang ceremony has been conducted since the reign of La Ummasa The 2 nd King of Bone even today is still done every year. This is because the Bone community is well aware of the values of local wisdom contained in this matompang arajang ceremony has a very important meaning for the life of bugis bone community (Syam, 2020).

Mattompang arajang is a sacral traditional ceremony by purifying bone royal heirlooms. Heirloom objects that are displayed include Teddung Pulaweng (golden umbrella), Sembangeng Pulaweng (gold sash), Kelewang LaTea Riduni, Keris La Makkawa, La Salaga, Alameng Tata Rappeng (Traditional weapon of seven or ade'Pitu). Washing bebda pusaka using 7 (seven) well water located in Bone
How to cite:

E-ISSN:

Published by:
Syam, Syahrianti, Mahmud Tang, Safriadi (2021) Symbolic Meaning of Sere Bissu in Matompang Arajang Ceremony for Bugis Bone Community, South Sulawesi. Jurnal of Social Science 2(4). https://doi.org/10.46799/jss.v2i4.175 2721-5202

Ridwan Institute 
Regency, namely purani bubung, bubung bissu, bubung lacokkong, bubung la garoang, bubung toro, bubung itello, and bubung manurung. The seven wells were collected as cleaning materials for the heirloom objects. Where the process of cleaning arajang is carried out by the bissu witnessed by the Bone Customary Council as well as religious and community leaders.

As a highly respected social community and has involvement in the implementation of mattompang arajang ceremony, Nurlina Syahrir bissu describes has several social functions which in this case are:

a. In its social function as a caretaker, nurse, and bearer of various heirloom objects commonly referred to as arajang, bissu have full authority in keeping the heirloom objects that are considered sacred because of their position which is also considered as a sacred community in Bugis society in general.

b. In its social function as the leader of ritual events, the bissu community is seen as having a consecrated soul so that they are considered capable of penetrating transcendental boundaries that connect them with the spirits of the ancestors even to the Creator. For example, in certain ceremonies with a very strong cultural dimension such as the Mattompang Arajang ceremony, the role of bissu as the leader of the ritual is still maintained in traditional ordinances.

c. In its social function as a shaman who in Bugis terms is commonly known as sanro, the bissu community is believed to have a deep knowledge of medicine because they are essentially seen as a community that has gained a lot of knowledge from the Creator as a logical consequence of their choice to devote themselves to the Creator by keeping a distance on worldly things.

d. In its social function as a guide for people who are getting married, the bissu community is considered to have a discerning view in understanding the relationship between men and women that will later be tied in a very sacred marital bond. In the process.

The various social functions of the bissu community above show that they have a very good position in the social strata of bugis bone community in particular and bugis community in general. However, over time, the level of dependence on the bissu community is decreasing due to several factors such as the number of bissu itself has been reduced in quantity, the more difficult access to be able to find a bissu figure because of their hard-toreach presence, and such. This is in line with what is stated by (Rahman, 2006), even if there is Bissu found now his role has also shifted, no longer as a clergyman, but some of them are only as leaders of ceremonial traditional ceremonies, and become brides and ceremonies and traditions that accompany it.

There are several studies related to the theme of this study, namely: Symbolism In The Ritual Speech In Mabbolo Ceremony Of Towani Tolotong In Amparita, Sidrap Regency (An Anthropolinguistic Study) by Astuti Akkas (Akkas, 2019). From this research shows that mabbolo ritual ceremony held in Amparita Village, Sidrap Regency is an annual activity conducted every January to ask god for protection. Mabbolo ceremony has a mantra spoken by Uwatta or Uwa" as the main character or as the leader of the towani tolotang community ritual. Mabbolo. Mabbolo rituals also have moral values and symbols that it has a meaning that has a relationship with human life.

Title "Culture of Bone Sere Bissu Maggiri Regency (Anita et.al, 2016). This paper concludes that one of the activities or rituals that are often performed bissu in Bone Regency itself is Sere bissu Maggiri. Sere bissu Maggiri is a dance performed by a bissu, therefore this dance is also known as mabbissu dance. Bissu is a male woman (transvestite) in Bugis belief who is entrusted to be the liaison between the gods in the sky and ordinary humans. Maggiri itself means poking kris into the body of bissu, especially to vital areas such as the neck, abdomen, and wrists. The bissu who perform this dance performance are considered to be possessed by spirits and get immune abilities to sharp weapons.

Research on Sere Bissu rituals in matompang arajang ceremony is important because no research has been found that explores in detail that fits the theme. A number of studies have been conducted, only reviewing the implementation and meaning of matompang arajang ceremony in general only. The research does not analyze the implementation alone, but rather decients the symbolic meaning of the Sere Bissu ritual contained in the matompang arajang 
ceremony. Thus there is a difference between previous research and this study.

\section{METHOD}

Research on the symbolic meaning of Sere Bissu contained in the ceremony matompang arajang conducted by the Bugis Bone community is qualitative with an ethnographic approach based on informant data. The determination of informants was chosen purposively, where researchers were more likely to choose informants who knew a lot about matompang arajang ceremonies. The informant was chosen based on the experience and knowledge of the matompang arajang ceremony, namely bissu, where all matompang arajang activities are conducted by bissu, and the customary council. The informant chosen to be interviewed in depth. The results of the study will be presented in the form of written words in the description of the informant and observable behavior about the ritual of Sere Bissu in bugis bone culture, especially matompang arajang ceremony.

In the process of data collection used interview guidelines or question grids as the basis for the formulation of questions. The research lasted for three months (JanuaryApril) in 2021 during the covid 19 pandemic. At the time of data retrieval, researchers conducted interviews directly to informants. Informants who participated in this study were interviewed for willingness and awareness. Questions are asked one by one openly in the atmosphere inside and outside the house. Some of the interviews were conducted via chating via WA and video calls. Informants are asked to share their experiences during follow or engage in matompang arajang ceremony. At the same time probing is done, which is a way of or investigate the answers given from the informant. then the researcher conducts a review of the informant that is to ask the informant again for the validity of the data obtained from the interview results.

The data is analyzed through three stages, namely: (1) data restatement, conducted by referring to interview excerpts based on the informant's point of view, (2) the description of the data, conducted to show the tendency of data concerning the symbolic meaning of Sere Bissu rituals in the matompang arajang ceremony, and (3) the process of data interpretation is carried out with regard to the context of the process, behavior and actions that are the basis in this research. The three stages of the analysis become the basis for drawing conclusions. Data taken from informants become supporting and supporting data that is mutually corroborating sourced from observation and documentation.

\section{RESULTS AND DISCUSSION}

\section{Mattompang Arajang Ceremony}

In its implementation, Mattompang Arajang ceremony is carried out with several stages that are related to each other which in this case can be described as follows:

a. Preparation of Mattompang Arajang Ceremony

1) Mappangolo

Mappangolo is the preliminary stage of the implementation of the ceremony Mattompang Arajang marked by the efforts of the bissu through their representatives to inform the king or the local government that it is time for the ceremony mattompang Arajang will be re-implemented.

2) Mappesabbi

Mappasebbi can also be interpreted by mappetabe that is to tell something as well as ask permission to the parties who have authority over what will be done in daily life.

3) Mattola Bala

Mattola Bala is a series of ceremonies mattompang Arajang as a form of request to the Creator so that the process of implementation of the ceremony Mattompang Arajang can run smoothly in accordance with what is expected.

4) Marekko Ota Marekko ota or offering which in this case is ota or betel leaf.
b. Mattompang Arajang Ceremony 1) Malekke Toja

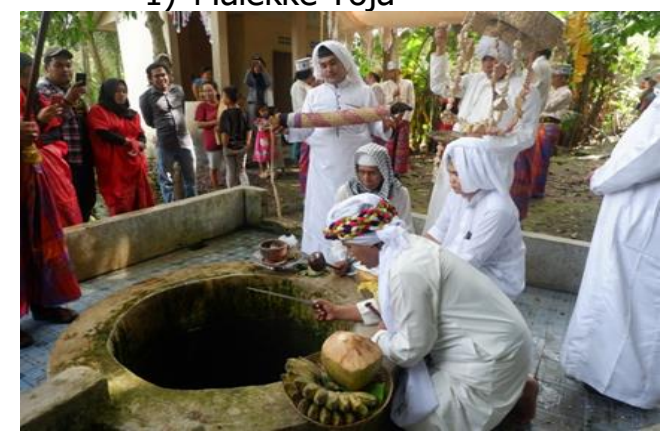


Picture of Malekke Toja

The next stage performed in the implementation of mattompang arajang ceremony is malekke toja which means water collection which will be used in washing relics of Bone Kingdom relics that are purified in the implementation of Mattompang Arajang ceremony. In its implementation, the water that can be used for this purpose is only water obtained at some wells that in this case are bissu wells (Bissu ridges) located in Barebbo Subdistrict, Parani wells (bubung Parani) located in Lamo Ape Village Palakka Subdistrict, Laccokkong wells (Laccokkong bubung) in Tanee Riattang Subdistrict, Tello' wells (tello') located in Tanete Riattang Subdistrict, toro well (bubung Toro) is located in Tanete Riattang Timur Subdistrict, La Garoang well (La Garoang bubung) in Tanete Riattang Subdistrict, and Manurung well (bubung Manurunge) are in Tanete Riattang Subdistrict. While the Kingdom of Bone still stands firm with its fortifications in the past as a sovereign Kingdom, the wells are considered sacred wells that have sacred value for the process of self-purification that is believed to be hereditary.

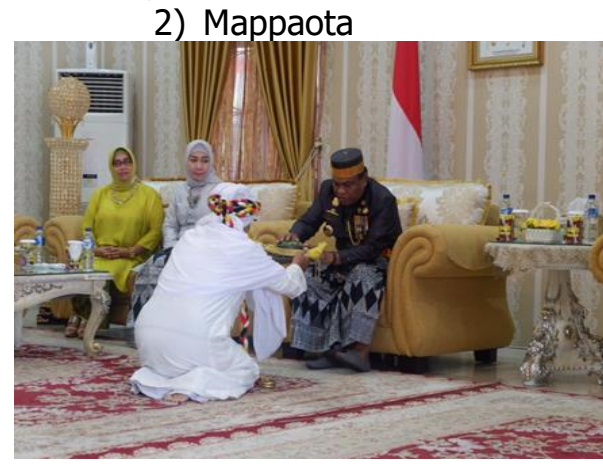

Picture of Mappaota

The next procession is mappaota where the indigenous stakeholders who are trusted to arrange the implementation of the ceremony Mattompang Arajang and bissu representatives face the regent of Bone as the device of the leader of the highest local government bone district to inform that the implementation of the ceremony Mattompang Arajang will be held soon. In the implementation of the ceremony Mattompang Arajang which is currently handled by the district government Bone as the person in charge, usually the role of the customary stakeholders is carried out by the head of the relevant office, especially those who handle cultural issues and preservation. This procession is called mappaota because the stakeholders or heads of related agencies, especially those who handle cultural issues and preservation with their entourage from bissu present betel leaves (ota leaves) that are placed on a cup at the Bone regent as a form of tribute. The sentences used in this process:

Bissu : "maraja addampeng batara tungke'na Bone: saniasani arajangna Bone maelo ritompang nassisabbingi tuana malebbikeng" lamarupe'"

Regent: "kuru' sumange 'lekkeni mai

Means :

Bissu : "I apologize to the supreme leader of Bone.It's time for Bone's arajang to be cleansed witnessed by you your majesty."

Regent: "Yes, do it."

The meaning of the above sentence that sacred objects (arajang) which is a sacred heritage of the Bone Kingdom is a symbol of dominance where the king with his authority is respected by the Bugis Bone community. The customary council or bissu asked the Regent of Bone for permission to clean the heirloom (Alifah, 2017) In the process of mappaota, it is illustrated how the dialogue between bissu as a community that has been trusted in terms of the implementation of mattompang arajang ceremony reported related to the implementation of the annual ritual.

3) Memmang To Rilangi

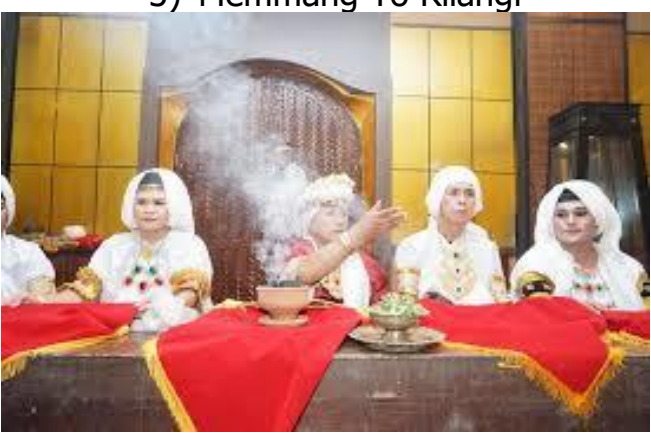

Memmang To Rilangi Images

Memmang To Rilangi is one of the series of mattompang arajang ceremony where the bissu as a community that is believed to have the ability to communicate with the torilangi language to read mantras 
as a permit application so that relics of the Bone Kingdom will soon be taken from its place for a while in order to be sanctified as an annual ritual that has colored the life of Bugis Bone from time to time. Memmang To Rilangi's Procession done by sounding a set of sounds such as ana baccing, buttons, drums, gongs, and others while the bissu that has been determined to do sere alusu.

Memmang to rilangi procession is a procession that has a trendsendental meaning in strengthening the spirit of the parties who will be directly involved in the purification of heirloom objects so that they avoid various disturbances that in impede the implementation of their duties. With a procession of memmang to rilangi that bridges the communication between the grounded underworld and the world above that perpetuates them ask the Creator so that they always get guidance and protection so that all series of Ceremonies Mattompang Arajang can be carried out smoothly from start to finish.

\section{4) Mattompang Arajang}

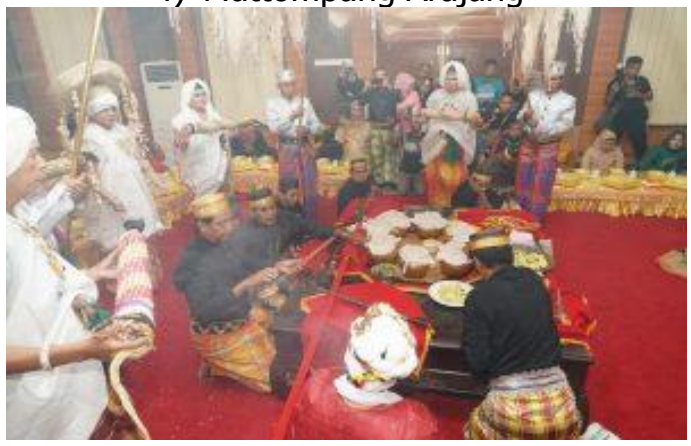

Mattompang Arajang Images

The procession of mattompang arajang is the core event of many series of events that accompany the implementation of mattompang arajang ceremony. It can be said that this procession of mattompang arajang is the culmination of various values that are imanen in the implementation of mattompang arajang ceremony. In its implementation, heirloom objects of bone kingdom that have been moved from their storage and ready to be sanctified are taken to pattompang who are ready to purify the heirloom objects. The procession was carried out by continuing to beat the drums of bali sumange which further adds to the sacred value of the procession, especially when Puang Matowa who is the vice chairman of adat took him to pattompang to be sanctified.

The bissu also did not miss to add to the sacred value of the procession by continuing to perform sere bissu with a movement that can be said to have passed through their trans physical consciousness and has transformed into their trans ruhaniyah by continuing to surround the pattompang who are purifying relics of the Bone Kingdom that are sanctified.

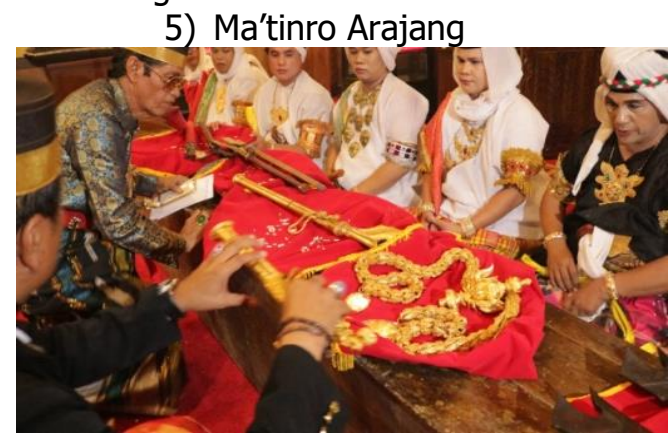

Ma'tinro Arajang Images

The next procession in the implementation of mattompang arajang ceremony is ma'tinro arajang where the relics of bone kingdom heritage that have been purified and then put to sleep in its original place. In the procession ma'tinro arajang, the heirloom objects are recited mantras using the language to rilangi which is also commonly referred to as mamemmeng. The procession of ma'tinro arajang at the ceremony of Mattompang Arajang can be illustrated by the form of sacred communication conducted by parties who have been directly involved in the implementation of mattompang arajang ceremony to the spirits of the ancestors who are believed to keep the relics of bone kingdom heritage tersbut that a series of processions mattompang arajang has been carried out. Therefore, the heirloom objects are then returned to their original place. The sentence used to restore the heirloom, namely:

Bissu: "purani ripepaccingi lamarupe' namaelo'ni rilekke maradde 'rionronna."

Regent: "talekkeni mai lamarupe' nameradde 'rionronna."

Means :

Bissu: "Arajang has been cleansed and will be brought back to his place."

Regent: "Take arajang to its original place well." 
The meaning of the above sentence is to speak of the bissu report to the Regent after the arajang is cleaned and ask permission to return the heirloom in its place (Alifah, 2017). The cleaned arajang needs to be rested in a sleep cycle, which in the context of sacred communication between the regent as a verticalcoordinated figure with his powerful social functions with bissu as a representative of Bugis Bone in general who is horizontalsubordinate with his social functions mastered, which is sound. Sleep in this context can be understood that when the procession mattompang arajang carried out, there is an active activity that is dialectical in it, especially between the arajang di-tompang with the parties directly involved in it which is very sacred without denying the existence of a profann dimension. In that context, various symbols that are faithless in both formal objects and material objects from one stage to another perform the process of transforming symbolic values in the social life of Bugis Bone. When the arajang is re-awakened where it will be rebuilt at the ceremony Mattompang Arajang the following year, the value is expected to continue to manifest in their social life.

In describing how the procession of ma'tinro arajang was conducted, AYPT suggested that the bissu usually tasked with doing will be conducting a form of sacred communication against relics of the Bone Kingdom that will be stored with the words"I save you (arajang) safely there in order to avoid the danger of catastrophe that will befall this".

c. Closing Ceremony of Mattompang Arajang

After the matompang arajang event is finished, the next event as well as the closing ceremony of matompang arajang ceremony is the cleaning of other heirloom objects owned by guests, where the water cleaned is the rest of the matompang water and ended with a meal together by serving traditional Bugis food such as doko-doko, barongko, biji nangka, cucuru bayau, and so on.

The series of mattompang arajang ceremony has a meaning that is loaded with symbols of transcendental value that bugis bone needs to contemplate from generation to generation. This shows that cultural expression is an expression that is done through symbol media that needs to be interpreted comprehensively and holistically.

2. Sere Bissu Ritual in Mattompang Arajang Ceremony

The ritual procession of Sere Bissu in Mattompang Arajang ceremony consists of three parts, namely the opening, filling, and closing (Alifah, 2017). In this case it can be explained, as follows :

a. unveiling

In the opening session of Sere Bissu, the speakers first began to greet important people in the community such as Bone Regent, religious leaders, and all guests who attended mattompang arajang celebration. After that, the speaker begins the procession by reciting the mantra Sere Bissu. They invited their ancestors by reading prayers and praises for their ancestors. The opening of the ritual mantra of Sere Bissu in Mattompang is recited by Puang Matowa as follows :

Teks 1

1) Tedduka' denramaningo

2) Gojenga' denramalettung

3) Malettungti ale Luwe

4) Maningoriwatampare

The meaning of the expression in text 1 is about the call of the bissu to be awakened by a noble man referring to the king of bone kingdom who lay in Luwu and slept in his house. Through God's expression, the king of bone kingdom will awaken from his sleep.

After the text was repeated three times, bissu sat around Puang Matoa while reciting prayers and praises to the ancestors as follows :

Teks 2

5) Tokkoko mutele-tule

6) Mutule-tule tinaju

7) Musaeng-saeng kenning

8) Musilanre-lanre kenning

9) Musinoreng musitoreng

10) Musiasaro lellangeng

11) Lolangeng mucokkangie

12) Lipu musarengrusie

The meaning of the expression in text 2 is to describe the desire of bissu to invite god to come show His radiant face. When Dewa came down, he 
immediately entered the body of bissu to perform Sere Bissu in Mattompang Arajang ceremony with a lively expression and produced a perfect performance. Bissu invited Dewa to come dance and sing along with bissu in Sere Bissu in Mattompang Arajang ceremony. After visiting each other, Dewa can climb again to his homeland in the sky.

b. fill

After reading prayers and praises, Puang Matowa and bissu surrounded arajang. Then Puang Matowa sang himself as follows :

Teks 3

13) 0 ........mpa 3x (PuangMatoa)

14) Ba....ta....ri $3 x$ (Bissu)

15) Urangeng-rangengnga' karaeng

16) Welongpelongna' karaeng

17) Tenawa' datu dewata

18) Pasolokka mula jajiku

19) Kupakariyo-riyoi

20) Kupaka wello-welloi

21) To ri wowo langiE

22) Datu ri sese bataraE

23) To ri to'dang talagaE

24) Siangka mae nasolo

25) Nonna'na mae ri lino

26) Nanyilu gau kawa

27) Nate'tengi paralesung

28) Rere wayu ri akasa

29) Nasanrang ri adeka

30) Ri papeng ri toasekku

31) Ri tangke Mario citta

The meaning of the phrase in text 3 explains that bissu who sang this ritual as an appreciation to the king who has brought his people into prosperity in the past. Bissu is considered a saint who possesses magic or sacred power but he always considers himself a royal advisor who must obey all the king's commands. In the spell implies that the glorified people of heaven, the glorified king of God, and the people under the honorable lake are invited by Bissu to come down into the world to see the attitude of man.

Then Puang Matoa began to show respect to the ancestors. He thrust the kris down his throat rhythmically. All dancers then have to follow Puang Matoa by sticking kris into various parts of their body seperti tangan, paha, perut, dan pelipis. Selama situasi yang sedang drums are hit, flutes are blown, and gongs are beat louder. At the moment, as the dance climaxes, the accompaniment music stops abruptly and the dancers remain in a standing position.

\section{CONCLUSION}

It turns out that the ritual of Sere Bissu in matompang arajang ceremony performed by bugis Bone community is loaded with symbolic values. Understanding bugis bone people that mattompang ceremony is a cultural heritage of the nation or ancestral wejangan that must be maintained and preserved as a vehicle for the formation of identity and identity. The findings of this study show that the process of implementation of matompang arajang ceremony consists of three stages, namely the preparation stage including mappangolo, mappesabbi, mattola bala, marekko Ota, the implementation stage consists of malekke toja, mapaota, memmang to rilangi, matompang to ma'tinro arajang, and the closing stage.

The ritual procession of Sere Bissu in Mattompang Arajang ceremony consists of three parts, namely opening, filling, and closing. Sere Bissu ritual in mattompang arajang ceremony has symbolic meaning as a form of sacred communication to God as well as to the spirits of bugis bone ancestors who they believe still exist around their lives.

This study is limited to bissu and customary councils only, not yet uniting the perspectives of community leaders and local governments including non-governmental organizations (NGOs), where they are participants and visitors. This is due to the pandemic covid 19 and time constraints in conducting research. Combining or uniting the perspectives of community leaders and local governments will allow for a comprehensive interpretation. In line with that, a follow-up research is needed that involves all aspects by accommodating the experience and knowledge of matompang arajang ceremony, especially Sere Bissu ritual. In order to keep the tradition and culture of matompang arajang ceremony to survive despite the development of technology and globalization is increasingly advanced. 


\section{REFERENCES}

Ahmad, Devi. 2016. "Aktivitas Komunikasi Upacara Adat Ngangsur Pusaka Makam Godog (Studi Etnografi Komunikasi Mengenai Aktivitas Ritual Dalam Upacara Ngangsur Pusaka Makam Godog Di Desa Lebak Agung Kabupaten Garut)." Universitas Komputer Indonesia Bandung.Google Scholer

Akkas, Astina. (2019). Symbolism In The Ritual Speech In Mabbolo Ceremony Of Towani Tolotang In Amparita, Sidrap Regency (An Anthropolinguistic Study). Universitas Hasanuddin.Goohgle Scholer

Alifah, Syarifah. (2017). Mattompang Arajang Ceremonial Procession in Bone Regency (A Semiotic Approach). Universitas Hasanuddin, Makassar.Google Scholer

Al-kheif, AM. 2020. "Ngumbah Lingga Sebagai Realitas Sakral Perspektif Mircea Eliade: Studi Deskriptif Milangkala Sa-Abad Lingga Di Alun Alun Sumedang." UIN Sunan Gunung Djati Bandung.Google Scholer

Aldianto, Rudi dkk. n.d. "Kesetaraan Gender Masyarakat Transmigrasi Etnis Jawa." Jurnal Equilibrium No. 1.Google Scholer

Anita dkk. (2016). Kebudayaan Daerah Kabupaten Bone Sere Bissu Maggiri. Makassar.Google Scholer

Arisal. 2017. "Nilai-Nilai Budaya Dalam Prosesiritual Mallangi Arajang Pada Masyarakat Bugis Soppeng Sulawesi Selatan." in Proceedings of National Seminar Research and Community Sercive Institute Universitas Negeri Makassar. Google Scholer

Arisal, dan Faisal. 2018. "Ritual Mattoana Arajang Di Kecamatan Lilirilau Kabupaten Soppeng." Jurnal Walasuji Vol. 9 (No. 2).Google Scholer
Darmapoetra, Juma. 2014. "Bissu: Perantara Dewa". Makassar: Arus Timur.Google Scholer

Fajriani. 2015. "Upacara Mappalil Oleh Pa'Bissu Di Kelurahan Bontomate'ne, Kecamatan Segeri, Kabupaten Pangkep." Universitas Islam Negeri Alauddin Makassar.Google Scholer

Fauzi, Rezza. 2017. "Fungsi Dan Mitos Upacara Adat Nyangku Di Desa Panjalu Kecamatan Panjalu Kabupaten Ciamis." Jurnal Seni Budaya Vol. 27 (No. 2).Google Scholer

Ilahi, Afiliasi. 2020. "Tradisi Jaman Pusaka dan Kereta Kencana di Kabupaten Pemalang." Jurnal Pangadereng Vol.6 (No. 1).Google Scholer

Indarwati, dkk. 2019. "Ritual Para Bissu, Para Waria Sakti Di Kabupaten Bone." Jurnal Idiomatik Vol. 2 (No. 2).Google Scholer

Indarwati, dkk. 2018. "Mattompang Arajang Prosesi Penyucian Benda Pusaka Kerajaan Bone: Tinjauan Semiotik Budaya." Jurnal Onoma: Pendidikan, Bahasa, Dan Sastra Vol. 6(No. 2).Google Scholer

Karasuta, Nadia. 2015a. "Perilaku Sakral Dan Profan Pada Upacara Adat Rebo Wekasan Di Desa Suci Kabupaten Gresik." Jurnal Mahasiswa Sosilogi Vol. 1(No. 1).Googel Scholer

Syam, Syahrianti dkk. (2020). Local Wisdom Values of The Matompang Arajang Ceremony In The Bugis Bone Community, South Sulawesi. European Journal of Research in Social Sciences, Vol. 8(No. 6).Goggle Scholer 
First publication right:

Journal of Social Science

This article is licensed under:

(cc) (i) 